\title{
A práxis do Reino de Deus como antecipação escatológica Um estudo a partir da Escatologia de Edward Schillebeeckx
}

\section{Orientador: Cesar Augusto Kuzma}

Doutorando: Aldo Fernandes da Rocha

Área de Concentração: Teologia Sistemático-Pastoral

Linha de Pesquisa: Fé e Cultura

Projeto de Pesquisa: A esperança cristã e as questões atuais da escatologia

A práxis do Reino de Deus na vida de Jesus Cristo e de seus discípulos se constitui como categoria teológica para a constatação da antecipação escatológica do Reino de Deus na História. Partindo da Escatologia presente nas obras de Edward Schillebeeckx, este estudo demonstra como o Reino de Deus, esperado para o futuro pós-histórico, antecipa-se na história mediante as práticas de justiça e de misericórdia a favor da vida plena para todos. Inicia-se com a demonstração da práxis do Reino de Deus presente nas obras do Autor, a fim de pôr em relevo a Escatologia presente em suas obras. A seguir, faz-se uma demonstração da cristologia escatológica de Schillebeeckx destacando a tipologia adotada pelo Autor, para se chegar ao contexto teológico e eclesial latinoamericano, a fim de demonstrar nele como o Reino é antecipado historicamente pela práxis dos discípulos do Reino na América Latina. O método usado nesta pesquisa foi o da revisão bibliográfica das obras de Schillebeeckx, em diálogo com outros teólogos e teólogas que tematizam ou se interessam pela temática da práxis do Reino de Deus. Da práxis de Cristo à práxis de seus discípulos, em todos os tempos, o Reino de Deus se antecipa e se manifesta na prática do amor, da verdade e da justiça, que socorre os pobres e lhes anuncia a esperança da salvação, já experimentada na caminhada na Terra, mas que terá seu acabamento no futuro glorioso e eterno em Deus. Desta Tese, a 
Escatologia recebe a contribuição temática aqui aprofundada, ao mesmo tempo em que a mesma Tese abre o caminho para ulteriores desenvolvimentos, a fim de enriquecer mais ainda a produção literária na área da Teologia Sistemática.

Palavras-chave: Práxis. Reino de Deus. Jesus Cristo. 